\title{
Corrigendum
}

\section{Pleiotropic actions of miR-21 highlight the critical role of deregulated stromal microRNAs during colorectal cancer progression}

MD Bullock, KM Pickard, BS Nielsen, AE Sayan, V Jenei, M Mellone, R Mitter, JN Primrose, GJ Thomas, GK Packham and AH Mirnezami

Cell Death and Disease (2013) 4, e748; doi:10.1038/cddis.2013.288; published online 1 August 2013

Correction to: Cell Death and Disease (2013) 4, e684; doi:10.1038/cddis.2013.213; published online 20 June 2013

Since the publication of this paper, the authors have noticed AH Mirnezami was spelt incorrectly. The correct spelling is shown above. The corrected article appears online together with this corrigendum.

The authors would like to apologize for any inconvenience this may have caused. 